\title{
Physical Properties of Spray Pyrolysed Cadmium Sulfide Thin Films Deposited on Different Polymer Substrates
}

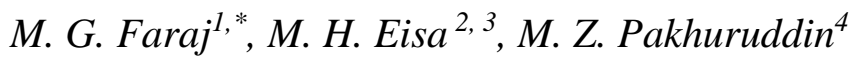 \\ ${ }^{1}$ Department of Physics, Faculty of Science and Health, Koya University Koya KOY45, Kurdistan \\ Region - F.R. Iraq \\ ${ }^{2}$ Physics Department, College of Science, Sudan University of Science Technology, Khartoum 11113, \\ Sudan \\ ${ }^{3}$ Departments of Physics, College of Sciences, Imam Mohammad Ibn Saud Islamic University \\ (IMSIU) Riyadh 11623, Saudi Arabia \\ ${ }^{4}$ Nano-Optoelectronics Research and Technology Laboratory, School of Physics, Universiti Sains \\ Malaysia, 11800 Minden, Penang, Malaysia. \\ *E-mail: mohammad.ghaffar@koyauniversity.org
}

doi: $10.20964 / 2019.11 .11$

Received: 10 June 2019 / Accepted: 13 August 2019 / Published: 7 October 2019

This paper investigates the properties of $80 \mathrm{~nm}$ cadmium sulfide $(\mathrm{CdS})$ thin films prepared by chemical spray pyrolysis technique on polyethylene terephthalate (PET) and polyimide (PI) plastic substrates at $250{ }^{0} \mathrm{C}$ for application as window layer in thin film solar cells. The influences of the type of substrate on the films' structural and optical features were studied. The patterns of diffraction of high resolution $\mathrm{X}$-ray show formation of hexagonal CdS structure. AFM reveals smooth surface morphologies of the films deposited on PET and PI substrates with root mean square (RMS) roughness of below $10 \mathrm{~nm}$. Optical transmittance exhibits values exceeding $70 \%$ in the visible and infrared (IR) regions on the two substrates. CdS deposited on PET records $2.48 \mathrm{eV}$ and CdS deposited on PI obtains $2.47 \mathrm{eV}$ of optical band gap $\left(E_{\mathrm{g}}\right)$ from Tauc plot. Hall measurements show that the CdS film is an n-type semiconducting material. The electrical resistivity, charge carrier mobility and carrier concentration of the CdS films deposited on PET and PI plastic substrates are 32.2 and $44.1 \Omega . \mathrm{cm}, 26.85$ and $31.08 \mathrm{~cm}^{2} \mathrm{v}^{-1} \mathrm{~s}^{-1}$ well as $5.2 \times 10^{17}$ and $6.78 \times 10^{17} \mathrm{~cm}^{-3}$ respectively.

Keywords: Semiconductors; Thin films; Optical properties; X-ray diffraction; Raman spectroscopy

\section{$\underline{\text { FULL TEXT }}$}

(C) 2019 The Authors. Published by ESG (www.electrochemsci.org). This article is an open access article distributed under the terms and conditions of the Creative Commons Attribution license (http://creativecommons.org/licenses/by/4.0/). 